\title{
Senam Prolanis Menurunkan Tekanan Darah Lansia Penderita Hipertensi
}

\author{
Adha Reza Fahlevi ${ }^{*}$, Agung Riyadi $^{2}$, Mardiani $^{3}$ \\ ${ }^{1}$ Prodi DIV Keperawatan, Poltekkes Kemenkes Bengkulu, Bengkulu, Indonesia \\ 2,3 Jurusan Keperawatan, Poltekkes Kemenkes Bengkulu, Bengkulu, Indonesia \\ *adharezafahlevi324@gmail.com
}

\begin{abstract}
Hypertension is the cause of death of about $12.8 \%$ of total deaths in the world. Based on data obtained from Talang Tinggi Public Health Center in 2017 the number of elderly people with hypertension reached 223 people, one of the handling that can control blood pressure is gymnastics. The purpose of this research was to determine the effect of Prolanis gymnastics (Chronic Disease Management Program) to blood pressure elderly patients with hypertension.This research was an analytic study with quasi experiment. The sample was a mild hypertension patient with age $\geq 60$ years old, amounting to 34 people consisting of 17 people in the intervention group and 17 people in the control group. The sampling technique was simple random sampling. Data analysis was used wilcoxon and mann-whitney test.The results of this study showed that there was an effect between Prolanis gymnastics on decline blood pressure of elderly hypertension patients in the intervention group before and after Prolanis gymnastics with $p$ value of systolic blood pressure $(p=0.001), p$ value of diastolic blood pressure $(p=0.001)$. Prolanis gymnastics beneficial for elderly people with hypertension to control and manage the disease experienced. Prolanis gymnastics is expected to be active as a hypertension control program.
\end{abstract}

Keyword: hypertension, elderly, prolanis gymnastic, blood pressure

\begin{abstract}
Abstrak
Hipertensi merupakan penyebab kematian sekitar 12,8\% dari jumlah total kematian di dunia. Berdasarkan data yang diperoleh dari Puskesmas Talang Tinggi tahun 2017 jumlah lanjut usia (lansia) penderita hipertensi mencapai 223 orang. Salah satu penanganan yang dapat mengontrol tekanan darah adalah senam prolanis. Tujuan penelitian untuk mengetahui pengaruh senam Prolanis (Program Pengelolaan Penyakit Kronis) terhadap tekanan darah lansia penderita hipertensi. Jenis penelitian ini merupakan studi analitik dengan desain quasi ekperimen. Sampel adalah penderita hipertensi ringan dengan usia $\geq 60$ tahun yang berjumlah 34 orang terdiri dari 17 orang pada kelompok intervensi dan 17 orang pada kelompok kontrol. Teknik sampling menggunakan simple random sampling. Analisis data menggunakan uji wilcoxon dan mann whitney. Hasil penelitian ini menunjukkan terdapat pengaruh senam Prolanis terhadap penurunan tekanan darah lansia penderita hipertensi dengan $p$ value tekanan darah sistolik $(p=0,001), p$ value tekanan darah diastolik $(p=0,001)$. Senam Prolanis bermanfaat bagi lansia penderita hipertensi untuk mongontrol dan mengelola penyakit yang dialami. Senam Prolanis diharapkan terus aktif sebagai program pengendalian hipertensi.
\end{abstract}

Kata kunci: hipertensi, lansia, senam prolanis, tekanan darah

Jurnal Keperawatan Raflesia, Volume 1 Nomor 2, November 2019

ISSN: (p) 2656-6222 (e) 2657-1595, DOI 10.33088/jkr.vli2.401

Available online: https://jurnal.poltekkes-kemenkes-bengkulu.ac.id/index.php/jkr 


\section{PENDAHULUAN}

Lansia adalah seseorang yang telah mencapai usia 60 (enam puluh) atau lebih. Jumlah lansia di Indonesia pada tahun 2000 sekitar 15 juta jiwa atau 7,2\% dari total populasi. Jumlah penduduk lansia ini meningkat menjadi sekitar 19 juta jiwa $(8,5 \%)$ pada tahun 2006 dan meningkat lagi menjadi 24 juta jiwa $(9,7 \%)$ pada tahun 2010. Diperkirakan akan berjumlah 29 juta orang $(11,4 \%)$ pada tahun 2020 . Dari data ini dapat kita ketahui bahwa jumlah lansia cenderung meningkat (Riskesdas, 2013; Kemenkes RI, 2014 ).

Semakin panjang umur lansia maka, semakin tinggi pula risiko terkena penyakit. Lansia mudah terkena penyakit karena berkurangnya daya tahan tubuh dan menurunnya efisiensi mekanisme homeostatis. Hipertensi merupakan penyakit yang paling sering menyerang lansia yaitu $57,6 \%$. Hipertensi merupakan penyebab kematian sekitar 7,5 juta kematian atau menyumbang $12,8 \%$ dari semua kematian di dunia (WHO, 2013).

Hipertensi adalah peningkatan tekanan darah diatas normal. Hipertensi menurunkan umur harapan hidup lansia. Banyak lansia yang menderita hipertensi tidak menyadarinya terutama hipertensi ringan. Hipertensi ringan yang tidak terawat cenderung menjadi hipertensi berat dan dapat menyebabkan komplikasi. Lansia yang menderita hipertensi dapat terkena stroke, gagal ginjal dan serangan jantung (Dalimartha, 2013). Selain itu Benetos, Petrovic \& Stranberg (2019) mengidentifikasi dampak hipertensi kepada lansia antara lain penyakit kardiovaskuler dan penurunan pada fungsi neurokognitif pada lansia.
Prevalensi hipertensi pada usia lansia (umur $\geq 60$ tahun) di Indonesia sebesar 65,4\% (Riskesdas, 2007). Hipertensi di Indonesia meningkat prevalensinya dari tahun 2007 yaitu sejumlah 7,6\% dan menjadi 9,5\% pada tahun 2013 (Riskesdas, 2013). Berdasarkan data dari Riskesdas tahun 2013, terjadi peningkatan prevalensi hipertensi di Bengkulu tahun 2007 sebesar $20,3 \%$ menjadi $21,6 \%$ pada tahun 2013 (Riskesdas, 2013).

Di provinsi Bengkulu jumlah lansia pada tahun 2011 adalah 99 ribu jiwa dan tahun 2012 jumlah lansia meningkat menjadi 103 ribu jiwa serta tahun 2013 jumlah lansia meningkat menjadi 109 ribu jiwa. Diperkirakan jumlah lansia akan terus bertambah banyak setiap tahun (Badan Pusat Statistik, 2015).

Studi pendahuluan yang dilakukan di Puskesmas Talang Tinggi didapatkan penyakit hipertensi menjadi salah satu penyakit nomor 3 dengan jumlah penderita hipertensi mencapai 301 orang. Jumlah lansia penderita hipertensi mencapai 223 orang dengan jumlah kunjungan perbulan sebanyak 48 kali pada tahun 2017 (Puskesmas Talang Tinggi, 2017).

Peningkatan prevalensi lansia penderita hipertensi dapat disebabkan oleh jarangnya lansia melakukan aktivitas fisik atau olahraga (Suryanto, 2010). Hipertensi apabila dibiarkan dapat menjadi masalah yang serius. Perlu dilakukan berbagai upaya mengontrol hipertensi. Upaya yang dapat dilakukan yaitu dengan memanfaatkan Prolanis (Program Pengelolaan Penyakit Kronis) yang terdapat di Puskesmas (Safitri \& Astuti, 
2017). Salah satu kegiatan Prolanis adalah melakukan senam Prolanis yang dilakukan secara teratur.

Senam prolanis merupakan salah satu bentuk olahraga. Senam prolanis meningkatkan daya tahan paru-paru dan jantung. Peningkatan aktifitas saat senam, akan meningkatkan metabolisme dan membakar lemak, serta mencegah terjadinya penyakit kardiovaskuler seperti stroke dan penyakit jantung (Lutfiasih \& Nailul, 2018).

Tujuan penelitian ini adalah untuk mengetahui pengaruh senam Prolanis (Program Pengelolaan Penyakit Kronis) terhadap tekanan darah lansia penderita hipertensi baik tekanan darah sistolik maupun diastolik.

\section{METODE}

Jenis penelitian ini merupakan studi analitik menggunakan jenis desain quasi eksperimen dengan untreated control group design with pre test and post test. Penelitian dilaksanakan di wilayah kerja Puskesmas Talang Tinggi Kabupaten Seluma Provinsi Bengkulu. Sampel adalah penderita hipertensi ringan dengan usia $\geq$ 60 tahun yang berjumlah 34 orang, yaitu 17 orang pada kelompok intervensi dan 17 orang pada kelompok kontrol.

Teknik sampling menggunakan simple random sampling. Intervensi yang dilaksanakan berupa senam prolanis yang meliputi pemanasan 5 menit, gerakan inti 20 menit dan pendinginan 5 menit. Uji normalitas data pada penelitian ini menggunakan uji kolmogorov-smirnov yang menunjukkan (tekanan darah sistolik dan diastolik baik sebelum ataupun setelah senam Prolanis) bahwa data tidak berdistribusi dengan normal.

Analisis bivariat pada penelitian ini menggunakan uji wilcoxon signed ranks test dengan $\alpha 5 \%$, untuk mengidentifikasi adanya perbedaan pada rata-rata tekanan darah sistolik dan diastolik antara sebelum dan setelah senam prolanis. Uji mannwhitney dengan $\alpha$ 5\% digunakan untuk mengetahui perbedaan tekanan darah sistolik dan diastolik pada kelompok yang berbeda yaitu tekanan darah sebelum dan setelah intervensi.

\section{HASIL}

Tabel 1. Karakteristik Responden di Puskesmas Talang Tinggi

\begin{tabular}{lcc}
\hline Karakteristik & Intervensi & Kontrol \\
\hline Usia & & \\
Mean & 71,06 & 62,41 \\
Median & 70 & 61 \\
SD & 6,240 & 2,623 \\
Min-Maks & $63-82$ & $60-68$ \\
CI for Mean & $67,85-74,27$ & $61,06-63,76$ \\
95\% & & \\
& & \\
JenisKelamin & & \\
Laki-laki & $7(41,2 \%)$ & $4(23,5 \%)$ \\
Perempuan & $10(58,8 \%)$ & $13(76,5 \%)$ \\
& & \\
\hline
\end{tabular}

Tabel 1 mengungkapkan bahwa karakteristik lansia dalam penelitian ini, terdiri dari usia dan jenis kelamin. Adapun usia responden kelompok intervensi adalah 63 tahun sampai 82 tahun dan rata-rata nya 71,06 tahun. Sedangkan pada kelompok kontrol adalah 60 tahun sampai 68 tahun dengan rata-rata 62,41 tahun. Jenis kelamin lansia pada kelompok yang diberikan intervensi sebagian besar $(58,8 \%)$ perempuan dan sebagian besar $(76,5 \%)$ pada kelompok kontrol juga perempuan. 
Tabel 2. Pengaruh Senam Prolanis Terhadap PenurunanTekanan Darah Sistolik dan Diastolik Pada Kelompok Intervensi

\begin{tabular}{|c|c|c|c|c|}
\hline Variabel & Mean & $\Delta$ Mean & $S D$ & $\begin{array}{c}p \\
\text { value }\end{array}$ \\
\hline $\begin{array}{l}\text { Tekanan } \\
\text { darah } \\
\text { sistolik }\end{array}$ & & & & \\
\hline Pre & 148,82 & 11,76 & 7,812 & $0,001 *$ \\
\hline Post & 137,06 & & 11,600 & \\
\hline $\begin{array}{l}\text { Tekanan } \\
\text { darah } \\
\text { diastolik }\end{array}$ & & & & \\
\hline $\begin{array}{l}\text { Pre } \\
\text { Post }\end{array}$ & $\begin{array}{l}97,65 \\
88,82\end{array}$ & 8,83 & $\begin{array}{c}6,642 \\
7,812\end{array}$ & $0,001^{*}$ \\
\hline
\end{tabular}

Tabel 2 menunjukan hasil analisis bahwa rata-rata nilai tekanan darah sistolik sebelum dan setelah senam Prolanis adalah 148,82 mmHg dan 137,06 mmHg. Hasil uji statistik menunjukkan nilai $p$ value 0,001 sehingga didapatkan kesimpulan bahwa ada pengaruh senam Prolanis terhadap penurunan tekanan darah sistolik lansia penderita hipertensi pada kelompok intervensi.

Sebelum senam prolanis, tekanan darah diastolik rata-rata adalah $97,65 \mathrm{mmHg}$, sedangkan setelah senam prolanis menjadi $88,82 \mathrm{mmHg}$. Hasil analisis menggunakan uji statistik ditemukan nilai $p$ value 0,001 . Dapat disimpulkan bahwa senam Prolanis berpengaruh terhadap nilai tekanan darah diastolik lansia penderita hipertensi pada kelompok intervensi.
Tabel 3. Pengaruh Senam Prolanis Terhadap Tekanan Darah Lansia pada Kelompok Intervensi dan Kontrol

\begin{tabular}{lcc}
\hline \multirow{1}{*}{ Variabel } & $\begin{array}{c}\text { Perbedaan Tekanan Darah } \\
\text { antara Kelompok Intervensi } \\
\text { dan Kontrol }\end{array}$ \\
\cline { 2 - 3 } & \multicolumn{1}{c}{$\Delta$ Mean } & p value \\
\hline $\begin{array}{l}\text { Tekanan } \\
\text { darah sistolik } \\
\text { pre-post }\end{array}$ & 11,17 & $0,000^{* *}$ \\
$\begin{array}{l}\text { Tekanan } \\
\text { darah } \\
\text { diastolik pre- } \\
\text { post }\end{array}$ & 8,24 & \\
*Wilcoxon & & \\
**Mann-Whitney & & \\
\end{tabular}

Tabel 3 menunjukkan perbedaan pada ratarata tekanan darah sistolik sebelum dan setelah senam prolanis antara kelompok yang diberikan intervensi dan kontrol adalah 11,17. Hasil uji statistik menunjukkan nilai $p$ value 0,000 dan dapat disimpulkan bahwa terdapat pengaruh senam prolanis terhadap penurunan nilai tekanan darah sistolik lansia penderita hipertensi.

Hasil analisis tekanan darah diastolik lansia penderita hipertensi pada kelompok intervensi dan kontrol menunjukan adanya perbedaan rata-rata pada tekanan darah diastolik sebelum dan setelah senam prolanis adalah 8,24. Hasil uji statistik menunjukkan nilai $p$ value 0,000 sehingga dapat disimpulkan bahwa senam prolanis berpengaruh terhadap penurunan tekanan darah diastolik lansia penderita hipertensi. 


\section{PEMBAHASAN}

Hasil penelitian menunjukan bahwa pada kelompok intervensi usia responden ratarata 71,06 tahun dan pada kelompok kontrol 62,41 tahun. Tekanan darah lansia meningkat disebabkan karena barkurangnya elastisitas arteri sentral (Jagadeesh, Balakumar, \& Maung-U, 2015). Menurut Benetos, Petrovic \& Stranberg (2019) penyebab utama peningkatan pada tekanan darah adalah kekakuan pada pembuluh darah arteri sebagai akibat dari perubahan struktural dan fungsional arteri besar. Perubahan usia menimbulkan dinding hipertrofi, kalsifikasi, lesi ateromatosa serta perubahan matriks ekstraseluler seperti peningkatan kolagen dan fibronektin, yang menyebabkan penurunan sifat elastis arteri dan pengembangan kekakuan arteri. Konstriksi dan penyempitan arteri menyebabkan meningkatnya tekanan darah diastolik. Penurunan kemampuan distensi untuk pelebaran pembuluh darah terutama pada aorta menyebabkan tekanan darah sistolik meningkat.

Sistem kardiovaskuler pada lansia sering menunjukan tanda klinis terjadinya penurunan fungsi. Fungsi sistem kardiovaskuler menurun karena sel otot jantung menurun akibat proses menua. Katup jantung kaku dan menebal serta dinding pembuluh darah aorta menjadi kurang elastis. Kemampuan jantung memompa darah turun $1 \%$ setiap tahun yang menyebabkan kontraksi dan volume darah juga turun. Curah jantung yang turun akan berdampak pada paru, otot, dan ginjal karena aliran darah ke organ tubuh berkurang (Wahjudi, 2008).
Kadar massa otot lansia mengalami penurunan hingga $40 \%$ dan sebagai gantinya terjadi peningkatan jaringan lemak. Lansia juga mengalami perubahan kekuatan otot, perubahan komposisi dan kekuatan tulang (Jeffry Tenggara, 2009). Kondisi ini menyebabkan lansia merasa lemah dan tidak ingin melakukan olahraga. Penurunan aktifitas dan peningkatan jaringan lemak membuat sirkulasi darah menjadi tidak lancar dan tekanan darah akan meningkat.

Sistem pembuluh darah perifer lansia mengalami perubahan struktural dan fungsional yang mengakibatkan perubahan tekanan darah. Perubahan ini salah satunya adalah aterosklerosis, hilangnya elastisitas jaringan ikat dan relaksasi pada otot polos pada pembuluh darah menjadi kurang. Pembuluh darah lansia mengalami penurunan kemampuan daya regang distensi. Kemampuan pembuluh darah arteri dan aorta dalam mengakomodasikan volume darah menjadi berkurang. Curah jantung menjadi kurang karena berkurangnya volume darah yang dipompakan oleh jantung, selain itu juga terjadi peningkatan tahanan perifer (Sherwood, 2011).

Hasil penelitian ini mengidentifikasi bahwa kelompok intervensi sebagian besar $(58,8 \%)$ lansia perempuan dan kelompok kontrol 76,5\% lansia perempuan. Hasil penelitian ini sejalan dengan penelitian Arif, Rusnoto, \& Hartinah (2013) yang menyatakan bahwa sebagian besar $(53,57 \%)$ lansia usia $\geq 60$ tahun yang menderita hipertensi adalah wanita. Wanita menopause menderita hipertensi lebih tinggi daripada pria. Kejadian hipertensi pada wanita menopause adalah $41 \%$. Wanita menopause mengalami 
aktivasi Sistem Renin Angiotensin (SAR) yang mengakibatkan peningkatan tekanan darah (Lewa, 2010).

Aktivasi SAR ditandai peningkatan aktivitas renin plasma. Komponen genetik dari SAR berperan dalam meningkatkan tekanan darah wanita menopause. Hipertensi pada wanita usia 40 sampai 70 tahun berhubungan dengan polimorfime gen renin. Kondisi ini tidak terjadi pada pria. SAR berperan dalam meningkatkan tekanan darah sehingga menjadi hipertensi tetapi bukan sebagai satu-satunya mediator (Lewa, 2010).

Androgen meningkatkan angiotensinogen yang menyebabkan peningkatan endotelin. Peningkatan endotelin yang terjadi karena penuaan merupakan faktor disfungsi endotel. Endotelin dapat berkontribusi terhadap terjadinya stres oksidatif. Stres oksidatif mengakibatkan pengurangan NO (nitritoksida) (Lewa, 2010).

Wanita pasca menopause ditandai terjadinya peningkatan stress oksidatif. Stres oksidatif pada wanita lansia terbukti dapat meningkatkan tekanan darah melalui mekanisme pengurangan bioviabilitas vasodilator yaitu NO (Lewa, 2010). Pengurangan produksi bioavailabilitas NO dapat menghambat vasodilatasi karena terjadinya konstriksi pembuluh darah. Blokade sintesis NO akan meningkatkan tekanan darah (Lippincott, Williams, \& Willy, 2008).

\section{Senam Prolanis Menurunkan Tekanan Darah pada Lansia Penderita Hipertensi}

Senam Prolanis mempunyai pengaruh yang signifikan terhadap keadaan tekanan darah sistolik dan diastolik pada lansia penderita hipertensi. Lansia yang mengikuti senam prolanis, maka tekanan darah sistolik dan diastoliknya menjadi turun (Lutfiasih \& Nailul, 2018). Senam prolanis meningkatkan kegiatan fisik dan aktivitas olahraga. Kegiatan fisik yang dilakukan secara teratur dapat menurunkan tekanan darah. Kegiatan olahraga dapat menurunkan nilai tekanan darah rata-rata 5-7 mmHg. Penurunan tekanan darah setelah berolahraga dapat berlangsung sampai 22 jam (Dalimartha, 2013).

Olahraga membuat tubuh menjadi kuat dan sehat. Olahraga menyebabkan sistem kardiovaskuler dan pernapasan juga menjadi lebih sehat sebagai respon homeostatik (Pescatello, et al., 2019). Olahraga yang baik dan sering dilaksanakan oleh penderita hipertensi adalah senam aerobik. Salah satu senam jenis aerobik adalah senam prolanis. Lansia yang menderita hipertensi ringan apabila melakukan senam prolanis secara teratur maka tekanan darah sistolik dan diastoliknya akan turun.

Senam prolanis merupakan jenis senam aerobic low impact. Senam prolanis memberikan beban yang rendah pada sendi disetiap gerakannya sehingga sesuai untuk lansia. Senam prolanis menggunakan seluruh otot tubuh dengan gerakan yang dinamis dan sederhana serta diiringi musik (Lutfiasih \& Nailul, 2018). Senam prolanis memberikan dampak yang positif bagi tubuh. Aliran darah keseluruh tubuh menjadi lebih lancar karena meningkatnya curah jantung. Paru - paru berfungsi optimal dalam mengambil $\mathrm{O}_{2}$ untuk kebutuhan metabolisme.

Senam prolanis dapat berpengaruh terhadap peningkatan efisiensi kerja 
jantung. Senam prolanis sebaiknya dilakukan dalam intensitas sedang yaitu denyut jantung 150-170 menit. Rentang intensitas sedang berada pada $60-90 \%$ dari keadaan denyut nadi maksimal seseorang (DNM) (Giriwijoyo S, S zafar, 2013). Lama satu kali senam prolanis sebaiknya 20 - 60 menit. Senam prolanis selama 20 menit akan meningkatkan penggunaan energi 20\%. Lemak didalam tubuh akan terbakar dan mengurangi beban kerja jantung.

Senam prolanis meningkatkan penggunaan oksigen dan glukosa. Kebutuhan oksigen meningkat hampir 20 kali lipat. Oksigen dan glukosa dibutuhkan oleh sel tubuh untuk pembentukan ATP (Afriwardi, 2009). Sistem kardiovaskuler berfungsi mendistribusikan oksigen dan nutrisi yang dibutuhkan otot untuk berkerja. Fungsi sistem kardiovaskuler akan meningkat pada saat senam prolanis untuk memenuhi kebutuhan oksigen serta mengangkut sisa metabolisme. Segera setelah Senam prolanis, pada pembuluh darah akan terjadi vasodilatasi dan aliran darah ke jaringan perifer menjadi lancar (Darmojo, 2012).

Menurut Mollaoglu (2015), tekanan darah pada penderita hipertensi dapat mengalami penurunan bila dilakukan senam prolanis secara teratur. Senam prolanis merangsang saraf parasimpatis sehingga aktifitasnya meningkat dan aktifitas saraf simpatis menjadi turun. Kondisi ini menyebabkan penurunan kadar hormon norepinefrin, katekolamin dan adrenalin, serta vasodilatasi (pelebaran) pembuluh darah. Sistem peredaran darah yang bekerja dengan membawa oksigen ke seluruh tubuh akan menjadi lebih lancar, sehingga tekanan darah akan menjadi turun (Safitri \& Astuti, 2017).
Senam Prolanis dapat merangsang baroreseptor yang merupakan refleks utama dalam mengontrol pengaturan tekanan darah dan denyut jantung. Tekanan dan peregangan pada sinus karotikus dan arkus aorta akan memberikan rangsangan terhadap baroreseptor. Peregangan pembuluh darah dan peningkatan tekanan darah arteri menyebabkan baroreseptor mengirimkan responnya dengan cepat ke pusat vasomotor dan mengakibatkan vasodilatasi pembuluh darah vena dan arteriol serta terjadi perubahan pada tekanan darah (Jagadeesh, Balakumar, \& Maung-U, 2015).

Dilatasi arteriol menyebabkan penurunan tahanan perifer. Darah pada pembuluh darah vena akan menumpuk karena dilatasi vena. Aliran balik vena berkurang dan curah jantung juga akan turun. Impuls aferen dari baroreseptor yang diterima jantung akan menghambat pusat simpatis (kardioaselerator) dan merangsang aktivitas saraf parasimpatis, sehingga menyebabkan penurunan daya kontraktilitas dan denyut jantung (Jagadeesh, Balakumar, \& Maung-U, 2015).

Senam Prolanis dapat menurunkan pelepasan katekolamin dan meningkatkan nitrooksida kedalam pembuluh darah. Konsentrasi nitrooksida meningkat dan konsentrasi katekolamin menjadi rendah dalam plasma darah (Dalimartha, 2013). Hal ini lah yang mengakibatkan tubuh menjadi rileks, denyut jantung dan tekanan darah menjadi turun.

Tekanan darah baik sistolik maupun diastolik dipengaruhi oleh tahanan perifer. Penurunan tahan perifer menyebabkan tekanan darah menjadi turun. Tahanan 
perifer dapat turun melalui beberapa mekanisme yaitu respon vascular, aktifasi sistem saraf simpatik dan system reninangiotensin (Sherwood, 2011). Senam prolanis kemungkinan dapat mengubah respon vasokonstriktor kuat menjadi vasodilatator sehingga memperlancar peredaran darah.

Senam prolanis bermanfaat bagi lansia. Senam prolanis meningkatkan kekuatan kapasitas paru dan kekuatan otot jantung. Sistem peredaran darah menjadi sehat dan kebutuhan $\mathrm{O}_{2}$ serta nutrisi kejaringan terpenuhi. Kondisi ini baik bagi kesehatan lansia karena mengurangi risiko terjadinya penyakit degenerative seperti penyakit jantung koroner dan hipertensi (Lewa, Pramantara, \& Rahayujati, 2010).

\section{KESIMPULAN}

Senam prolanis merupakan olahraga yang baik bagi lansia. Senam prolanis berpengaruh pada lansia yang menderita penyakit hipertensi yaitu dengan menurunkan tekanan darah. Tekanan darah yang turun bukan hanya tekanan sistolik tetapi juga diastolik. Senam prolanis sebaiknya dilakukan secara rutin minimal tiga kali seminggu. Petugas puskesmas diharapkan tetap melakukan dan mempromosikan senam prolanis sebagai salah satu cara mencegah peningkatan tekanan darah lansia di masyarakat.

\section{DAFTAR PUSTAKA}

Arif, D., Rusnoto., \& Hartinah, D. (2013). Faktor-faktor yang berhubungan dengan kejadian hipertensi di pusling desa kumplit upt puskesmas gribig kabupaten kudus. Jurnal Ilmu Keperawatan dan Kebidanan, 4(1), 18-34.
Afriwardi. (2009). Ilmu kedokteran olahraga. Jakarta: EGC.

Badan Pusat Statistik. (2015). Data sensus kependudukan provinsi bengkulu. Diunduh dari http:// bps.go.id/ pada tanggal 10 November 2017.

Benetos, A., Petrovic, M., \& Stranberg, T. (2019). Hypertension Management in Older and Frail Older Patients. Circulation Research, 1045-1060. doi: 10.1161/CIRCRESAHA.118.313236

Dalimartha, S, dkk. (2013). Care your self : Hypertension. Jakarta: Penebar Plus.

Darmojo, B. (2012). Buku ajar geriatri. Jakarta: Fakultas Kedokteran Universitas Indonesia.

Giriwijoyo S, \& Sidik, D. Z. (2013). Ilmu faal olahraga (fisiologi olahraga): Fungsi tubuh manusia pada olahraga untuk kesehatan dan prestasi. Bandung: PT. Remaja Rosdakarya.

Jagadeesh, G., Balakumar, P., \& Maung-U, K. (2015). Pathophysiology and pharmacotheraphy of cardiovascular disease. USA: Adis.

Jeffry Tenggara. (2009). Elderly exercise, olahraga untuk lanjut usia. Bag. I. FKUI-RSCM : Jakarta.

Kementrian Kesehatan Republik Indonesia. (2014). Situasi dan analisis lanjut usia. Jakarta: Kementrian Kesehatan Republik Indonesia.

Lewa, A. F., Pramantara, I. D. P., \& Rahayujati, T.B. (2010). Faktor-faktor resiko hipertensi sistolik terisolasi pada lanjut usia. Berita Kedokteran Masyarakat, 26(4), 171-178. doi: https://doi.org/10.22146/bkm.3456.

Lippincott, Wiliams \& Willy. (2008). Principles and practice of endocinology and metabolism. USA: Library of Congres. 
Lutfiasih R, \& Nailul A, (2018). Pengaruh senam prolanis terhadap penurunan tekanan darah pada lansia di desa glagahwero kecamatan panti kabupaten jember. Journal: The Indonesian journal of health science. doi: http://dx.doi.org/10.32528/ijhs.v0i0.153 9.

Mollaoglu, M., Solmaz. G., \& Mollaoglu, M. (2015). Adherence to therapy and quality of life in hypertensive patients. Acta Clinica Croatica, 54(4), 438-444. Diunduh dari https://www.researchgate.net/publicatio n/298821495_Adherence_to_therapy_a nd_quality_of_life_in_hypertensive_pat ients.

Pescatello, L. S., Buchner, D. M., Jakicic, J. M., Powell, K. E., Kraus, W. E., Bloodgood, B., ...Piercy, K.L. (2019). Physical activity to prevent and treat hypertension: A systematic review. American College of Sports Medicine, 1314-1323.

doi: 10.1249/MSS.0000000000001943.

Puskesmas Talang Tinggi. (2017). Data kunjungan pasien hipertensi periode tahun 2017. Seluma: Puskesmas Talang Tinggi Kabupaten Seluma.

Riset Kesehatan Dasar. (2007). Laporan nasional riset kesehatan dasar tahun 2013. Jakarta: Badan Penelitian dan Pengembangan Kesehatan Kementerian Kesehatan RI.

Riset Kesehatan Dasar. (2013). Laporan nasional riset kesehatan dasar tahun 2013. Jakarta: Badan Penelitian dan Pengembangan Kesehatan Kementerian Kesehatan RI.

Safitri, W., Astuti, H. P. (2017). Pengaruh senam hipertensi terhadap penurunan tekanan darah di desa blembem wilayah kerja puskesmas gondangrejo. Jurnal Kesehatan Kusuma Husada, 8(2). DOI: https://doi.org/10.34035/jk.v8i2.230.

Sherwood, L. (2011). Fisiologi manusia dari sel ke sistem. Jakarta: EGC.
Suryanto. (2010). Pentingnya olahraga bagi lansia. Medikora: Jurnal Ilmiah Kesehatan Olahraga, VI(1), 23-30.

Wahjudi, (2008). Keperawatan gerontik dan geriatrik. Jakarta: EGC.

WHO. (2013). A global brief on hypertension: Silent killer, global public health crisis. Diunduh dari http://ishworld.com/downloads/pdf/global_brief _hypertension.pdf. 


\section{HALAMAN INI SENGAJA DI KOSONGKAN}

